\title{
Kognisi Sosial Melalui Situs Jejaring Youtube Pada Komunitas Online (Studi Kasus pada Komunitas Online LinkPictureID)
}

\author{
Fitria Ayuningtyas, Ahmad Zakki Abdullah \\ Fakultas Ilmu Sosial dan Ilmu Politik, Universitas Pembangunan Nasional "Veteran” Jakarta \\ fitria.irwanto@upnvj.ac.id, amatzach@upnvj.ac.id
}

\begin{abstract}
The Video portal known as Youtube has become one of the alternative broadcasting channels. As the Internet usage is increasing the use of visual form becomes a public space. A YouTuber, a popular slang for video producer on youtube has formed a style of its own, in which there are some interesting research studies, especially in the establishment of reality and social cognition. Videos that teached the perspective and expression of opinion is an example of how the youtuber shapes reality to the audience. This video was varied, ranging from animation, social experiment up to the high-level animation. Social cognition is becoming prominance, that the audience use video logic as a basis for understanding the various things in surrounding environment. However, the capacity and the youtuber background are very wide - range as they have no common standard to their profession as videographer. The aim of this study is an effort to observe how Youtube users see the social situation as a cognitive ability form the use of video. This study used theory about social cognition, social media and youtube. This study used qualitative method. The result of this study is an interaction between users and creators create a whole different kind of dialogue, given in this era of communication technology they are none other than Prosumen (producer-consumer). The rapid reproduction of this message is very dynamic, especially responding to social circumstances. This study focuses on an active online community focusing on the interaction CMC via youtube video portals as the establishment of social cognition.The conclusion this study was social cognition thru youtube give us new perspective that we can get creative as well as possible to be able to work freely. In this study, the community used youtube as reference and benchmark. In this case, LinkPicture ID community well understand about "upgrade" concept that required to speed up in taking a decision based on the dynamics that happened.
\end{abstract}

Keywords: online community, social cognition, youtube users.

\begin{abstract}
Abstrak
Portal video Youtube telah menjadi salah satu saluran penyiaran alternatif. Penggunaan internet yang semakin meningkat membentuk sebuah ruang penggunaan visual yang bebas. Youtuber, sebutan untuk para produsen video di youtube telah membentuk sebuah nuansa tersendiri, didalamnya terdapat beberapa kajian kajian menarik terutama di pembentukan realita dan kognisi sosial. Video-video yang mengajarkan cara pandang dan pengungkapan opini maupun pendapat adalah contoh bagaimana para youtuber membentuk realita terhadap penontonnya. Kognisi sosial dalam pandangan ini sangatlah penting mengingat bahwa para penonton menggunakan logika video tersebut sebagai dasar dalam memahami berbagai hal disekitar lingkungannya. Namun demikian kapasitas maupun latar belakang para youtuber ini sangat bermacam-macam mengingat mereka
\end{abstract}


tidak memiliki standard umum terhadap profesi mereka sebagai videografis. Tujuan penelitian ini untuk melihat bagaimana pengguna youtube melihat keadaan sosial sebagai kemampuan koginitif. Teori yang digunakan dalam penelitian ini yaitu kognisi sosial, situs jaringan sosial, dan youtube. Penelitian ini menggunakan metode penelitian kualitatif. Adapun hasil dari penelitian ini adalah interaksi antar pengguna dan pembuat video merupakan interaksi yang sangat berbeda, mengingat di era teknologi komunikasi ini mereka tidak lain dari produsen-konsumen. Pesatnya reproduksi pesan ini sangatlah dinamis terutama menanggapi keadaan sosial. Penelitian ini memfokuskan diri pada sebuah komunitas online yang aktif dan mengutamakan interaksi CMC lewat portal video youtube sebagai pembentukan kognisi sosial. Kesimpulan kognisi sosial melalui youtube memberikan pandangan bahwa kita bisa berkreasi sebaik mungkin untuk bisa berkarya secara bebas. Adapun penggunaan youtube sebagai sebagai referensi dan pembanding. Dalam hal ini, komunitas LinkPictureID paham dengan konsep "upgrade" dimana diperlukan sebuah kecepatan dalam mengambil keputusan berdasarkan dinamika yang terjadi.

Kata Kunci: kognisi sosial, komunitas online, pengguna youtube.

\section{Pendahuluan}

\section{Latar Belakang}

Perkembangan ilmu komunikasi hingga saat ini merupakan hasil dari suatu proses perkembangan yang cukup panjang. Perkembangan teknologi telah menciptakan saluran media bagi pemasaran. Penggunaan yang tinggi dari perangkat ponsel dan dapat diakses dengan mudah menggunakan jaringan wireless berkecepatan tinggi yang membuat para marketer tertarik untuk menggunakan perantara ini.

Melihat kenyataan di tengah teknologi yang terus berkembang, maka tuntutan akan suatu produk pun semakin beragam dan terus menerus berkembang. Diantara kebutuhan primer dan sekunder terdapat pula kebutuhan tertier yang secara tidak langsung dibutuhkan oleh masyarakat kini.

Setelah kepopuleran Facebook dan Twitter pada tahun 2007, situs jejaring sosial media seperti Instagram $(I G)$ maupun Youtube mulai membentuk pola konsumsi yang lebih visual. Youtube adalah sebuah situs jejaring yang menawarkan sebuah pola interaksi yang agak unik, mengandalkan video sebagai konten. Kemunculan portal video seperti vimeo, metacafe, reddit, liveleak juga mengambil interaksi videografik yang serupa. Integrasi Youtube dengan korporasi Google yang dilengkapi dengan fitur Adsense adalah salah satu bentuk konvergensi "new media". Konten video Youtube dimungkinkan untuk disisipi iklan oleh Adsense melalui akun Google, sehingga pemilik video bisa diuntungkan Traffic pengguna dipantau dan dianalisis melalui Google analytic, terutama informasi interkasi akibat advertisement placement (penempatan iklan) tersebut. Dari informasi yang didapat dari laman video itu seperti jumlah view, impression, direct click, akan dibayarkan sejumlah uang kepada pemilik akun video tersebut. Inilah mekanisme "monetizing" sederhana yang dilakukan Adsense dari akun Youtube. 
Fitria Ayuningtyas, Ahmad Zakki Abdullah : Kognisi Sosial Melalui Situs Jejaring Youtube Pada Komunitas Online (Studi Kasus pada Komunitas Online LinkPictureID)

Pada tahun 2010, adalah era menjamurnya vlogger, caster, dan videographer yang menggunakan Youtube sebagai media penyiaran mereka. Mereka pun membentuk berbagai bentuk genre video mulai dari infographic, teledrama, motivasi, komedi, social experiment, webseries, compilation, toplist, commentary, dokumenter dan lainnya. Mereka membentuk sebuah komunitas yang aktif memproduksi konten Youtube melalui interaksi yang dinamis. Salah satu media arus utama dengan jurnalistik teater dan sinema yang berkantor di LA (Variety), akhirnya menerima Youtube sebagai media yang sangat berpengaruh. Sebagai media yang memiliki andil besar pada industri hiburan, awalnya Variety memiliki sifat restriktif terhadap digital konten. Akan tetapi akhirnya Variety mulai membahas channel Youtube dan mensponsori acara namun hanya memasukan konten atau pengguna yang berdomisili di A.S, seperti Anna Akana, Ray William Johnson. Akan tetapi pada tahun 2015 akhirnya Variety mulai meluaskan bahasan Youtube secara global. Felix Arvid Ulf Kjellberg atau lebih dikenal dengan nama "pewdipie", pengguna Youtube asal Swedia diakui sebagai orang yang sangat berpengaruh di dunia hiburan oleh Variety.

Melalui sistem monetizing dengan Adsense, Youtube adalah media penyiaran alternatif yang menyajikan konten visual. Monetizing media ini pun mulai digunakan oleh para pengguna Youtube di Indonesia. Penggunaan media internet yang tersegmentasi pada kalangan tertentu menghasilkan pioneer produsen Youtube pada konten-konten tertentu seperti Happy Day Production, malesbanget.com yang berfokus pada tema metropolitan dan urban atau mengacu pada bahasan trend dan popularisme dengan target pasar eksklusif. Pola segmentasi ini berimbas pada penggunaan dan konten yang juga membentuk komunitas yang berbeda. Pada tahun 2011, penggunaan konten Youtube mulai bergeser ke konten yang sedikit berbeda. Mereka disebut sebagai blackhat user. Di Indonesia, karena tidak adanya penegakan hukum yang tegas pada pelanggaran HAKI membuat Youtube lahan yang subur bagi blackhat. Para pengguna akun Youtube yang tergolong blackhat bukanlah peretas namun mereka melanggar hak cipta atau intelektual, dengan mengunggah materi suntingan yang bersumber dari siaran lain seperti stasiun TV, sosial media atau media berita tanpa izin para pemilik. Konten yang diunggah biasanya mengandung fenomena sosial yang sensasional seperti skandal dan eksploitasi dalam bentuk bahasa, kekerasan maupun seks. Salah kontennya adalah gosip mengenai selebritis, dokumentar personal tokoh publik, atau kumpulan dan kompilasi cuplikan dari berbagai acara TV yang telah disunting seperti Indonesian Lawyers Club (ditayangkan di TvOne), Fesbuker (acara komedi), Dahsyat (acara pentas lagu pop) dan sebagainya. Adapun konten yang generik, yaitu konten yang diproduksi sendiri tanpa harus meminta izin ke pihak manapun namun masih menggunakan eksplotasi adalah tayangan seperti dokumenter pentas dangdut koplo, adegan perkelahian dan lainnya.

Konten abu-abu adalah konten yang masih menggunakan materi pihak lain namun mengacu pada fair use namun masih agresif mengejar. Dan didalam itu masih ada sebuah network. Komunitas semacam ini adalah sebuah jaringan produsen yang terintegrasi dimana anggotanya dijanjikan traffic yang lebih besar dengan pengawasan materi yang lebih baik. Akan tetapi masih ada dari para 
pengguna Youtube yang benar - benar generik tanpa menggunakan eksploitasi seperti konten kuliner, vlogger, podcast, video test, product reviewer dan lainnya. Salah satunya ada channel Youtube "Jakarte Street Food" yang berisikan tayangan ulasan mengenai makanan atau jajanan kaki lima. Channel "Sacha Stevenson" yang berisikan tayangan tema Indonesia namun melalui perspektif budaya. Channel Skinnyindonesian24 yang berisikan tayangan bertema anak muda dengan gaya humor dan masih banyak lagi. Dalam melihat fenomena ini tentu harus ada kegunaan yang bisa diarahkan dan dikembangkan sehingga membawa manfaat bagi para pengguna maupun para khalayak umum. Salah satu pengembangan yang sangat menarik adalah pengelolaan pengetahuan (knowledge management) yang berkenaan dengan identitas sebuah komunitas.

Komunitas adalah salah satu bentuk organisasi kecil namun bisa memberikan pengaruh yang besar bagi para anggotanya. Participatory Culture dalam interaksi digital dapat membentuk perilaku kognitif, apalagi dengan media Youtube yang terintegrasi secara visual. Perilaku ini dapat membentuk sebuah kognisi yang signifikan terutama untuk proses pendidikan. Pentingnya signifikansi ini pada implementasi interaksi sosial ini sangat penting sehingga diperlukan sebuah forum komunikasi yang lebih besar sehingga dapat menjadi pendorong dalam membentuk masyarakat komunikasi yang generik di Indonesia. Dengan demikian hasil penelitian ini memiliki harapan besar agar bisa diterbitkan di Jurnal Ilmiah Nasional yang terakreditasi agar dapat menjangkau para pengguna yang lebih luas dan terprogram secara optimal.

\section{Rumusan Masalah}

Seperti yang telah dibahas diatas ada sebuah perilaku pengguna yang sangat agresif terhadap pendapatan Adsense. Hal ini memang harus dibahas lebih lanjut dengan tujuan bisa membentuk kelayakan dan kepantasan pada penggunaan youtube. Terutama menumbuhkan kesadaran pada sebuah komunitas tentang pengelolaan pengetahuan dengan menggunakan youtube. Sehingga perumusan masalah dalam penelitian ini adalah : Bagaimana proses terjadinya kognisi sosial secara internal maupun eksternal pada komunitas online?

Hasil akhir dari penelitian ini sekiranya dapat memberikan petunjuk tentang perilaku masif terhadap konsumerisme dan produksi konten pada kalangan terbatas.

\section{Tujuan Penelitian}

Berdasarkan latar belakang dan perumusan masalah di atas, maka tujuan dari penelitian ini adalah untuk mengetahui bagaimana proses terjadinya kognisi sosial secara internal maupun eksternal pada komunitas online?

\section{Manfaat Penelitian}

Manfaat yang dapat dibagi peneliti ini adalah sebagai berikut : (1) Penelitian ini di harapkan dapat mengembangkan ilmu yang sudah di dapat, referensi bagi peneliti-peneliti selanjutnya agar menunjang perkembangan dalam ilmu komunikasi. Dengan adanya penelitian ini diharapkan dapat menambah wawasan pembaca tentang kognisi sosial melalui situs jejaringan pada komunitas. 
Fitria Ayuningtyas, Ahmad Zakki Abdullah : Kognisi Sosial Melalui Situs Jejaring Youtube Pada Komunitas Online (Studi Kasus pada Komunitas Online LinkPictureID)

(2) Penelitian ini diharapkan dapat membantu memberikan pengetahuan lebih luas tentang kognisi sosial melalui situs jejaringan pada komunitas.

\section{Kognisi sosial}

Kognisi Sosial menurut Barn \& Byne (2000) dalam http://www.psikologiku.com/pengertian-kognisi-sosial-dalam-psikologi-sosial/ diakses pada tanggal 10 Mei 2017 merupakan cara individu untuk menganalisa, mengingat dan menggunakan informasi mengenai kejadian atau peristiwaperistiwa sosial. Bagaimana cara kita berpikir tentang dunia sosial, bagaimana cara kita mencoba untuk memahaminya dan bagaimana cara kita memahami diri kita dan tempat kita di dalam dunia itu menurut Bargh (1999) dalam http://www.psikologiku.com/pengertian-kognisi-sosial-dalam-psikologi-sosial/ diakses pada tanggal 10 Mei 2017. Kognisi sosial kita berfungsi secara "otomatis", cepat, tanpa usaha dan tanpa penalaran yang cermat atau logis karena telah ada skema yang membimbing kita dalam menganalisa suatu peristiwa terdapat 3 proses yaitu : attention : proses pertama kali terjadi dimana individu memperhatikan gejala-gejala sosial yang ada disekelilingnya, encoding : memasukkan apa yang diperhatikan ke dalam memorinya dan menyimpannya, retrieval : apabila kita menemukan gejala yang mirip kita akan mengeluarkan ingatan kita dan membandingkan apabila ternyata sama maka kita bisa mengatakan sesuatu mengenai gejala tersebut atau bisa juga individu mengeluarkan ingatannya ketika akan menceritakan peristiwa yang dialami. Dalam kognisi sosial dikenal istilah skema yang merupakan semacam kerangka atau gambaran yang membantu individu dalam mengorganisasikan informasiinformasi suatu fenomena yang diperhatikan individu. Terdapat 3 macam jenis skema, yaitu: person : gambaran mengenai atribut-atribut atau ciri-ciri dari individu lain atau diri individu itu sendiri, roles : gambaran mengenai tugas dan peranan individu-individu di sekeliling kita, events : gambaran mengenai peristiwa-peristiwa sosial yang dialami atau dilihat individu sehari-hari.

Pembahasan yang terjadi seputar kegiatan produksi Youtube biasanya diidentifikasikan sebagai tempat "bersantai" remaja. Relevansi remaja dan pembentukan ruang interaksi ini bergeser ke media online dan dengan teknologi yang ditawarkan, mereka berbagi konten yang mereka buat sendiri dan sekaligus membentuk hubungan sosial. Para peneliti melihat ini sebagai ruang virtual yang menjadi gerbang komunikasi anak-anak muda dengan pengguna, yang keikutsertaannya terjadi pada wacana publik, pencarian identitas, dan mendapatkan keahlian baru menurut Chau (2010).

Masyarakat informasi memiliki akses teknologi yang sangat besar sehingga bisa melakukan produksi dengan sendiri. Dalam pemahaman ini Youtube adalah konvergensi new media, yang tediri atas unsur komunikasi, komputerisasi dan konten. Komputerisasi menyangkut hal teknis diantara masalah koneksi, akses, perangkat keras komputer dan lain sebagainya. Sedangkan komunikasi menyangkut hal teknologikal, seperti bagaimana pengaruh, perilaku penonton, komunitas, dampak sosial dan sebagainya. Sedangkan konten membahas pengelolaan multimedia dalam produksi video. Konvergensi inipun diantaranya menyertakan konsep konten yang berpihak pada penonton, mengandalkan 
interaksi partisipan, pembentukan pengguna prosumen (produsen sekaligus konsumen).

Materi audio/visual memiliki jangkauan yang lebih luas dengan upaya produksi yang praktis, sehingga bentuk kognisi visual dalam era ini sangatlah tinggi. Disinilah pentingnya kita memahami bagaimana interaksi bisa terjadi dengan mengkaji berbagai pendekatan, inilah konvergensi pada hakikatnya; gabungan dari berbagai sumber. Fenomena Youtube ini terindikasi sebagai konversi wacana akibat konvergensi teknologi; yakni kesenangan menjadi daya kerja menurut Postigo (2014). Konsep ini dipahami melalui 3 pendekatan yaitu the garden, the machine dan the game.

Berikut adalah penjelasan dari masing-masing pendekatan tersebut :

a) The garden adalah konsep yang paling mendasar terdiri atas UGC (user generated content), labor, dan participation.

b) The machine adalah konsep yang membahas teknis (technical architecture), akses (affordance) dan fasilitas (features).

c) The game: value dalam masalah ini adalah mekanise monetizing dan Adsense.

Secara konvergensi, ketiga bahasan ini mencakup semua capaian yang menjadi sumber dalam konvergensi. Dalam hal ini juga peneliti mengajukan sebuah pemaham yang lebih menyuluruh yang juga menjadi bagian dari bahasan sebelumnya mengenai 3 C's of convergence.

\section{Situs Jaringan Sosial}

Jaringan sosial adalah sebuah pola koneksi dalam hubungan sosial individu, kelompok dan berbagai bentuk kolektif lainnya. Hubungan ini bisa berupa hubungan interpersonal atau bisa juga bersifat ekonomi, politik atau hubungan sosial lainnya (http://arti-definisi-pengertian.info/pengertian-jaringansosial/ diakses pada tanggal 10 Maret 2017).

Jaringan sosial memiliki konsep menunjukkan suatu hubungan sosial yang diikat oleh adanya kepercayaan dan kepercayaan itu dipertahankan dan dijaga oleh norma-norma yang ada. Pada dasarnya jaringan sosial terbentuk karena adanya rasa saling tahu, saling menginformasikan, saling mengingatkan, dan saling membantu dalam melaksanakan ataupun mengatasi sesuatu.Teori jaringan sosial menilai bahwa setiap aktor (individual atau kelompok) memiliki akses berbeda terhadap sumber daya (kekayaan, kekuasaan, informasi). Teori jaringan termasuk bagian dasarnya kapital sosial, terdiri dari tiga dimensi utama yakni kepercayaan (trust), norma, dan jaringan (network). Berdasar sifatnya, kapital sosial dapat bersifat mengikat (bonding), menyambung (bridging), dan bisa pula bersifat mengait (linking).

Jaringan sosial merupakan suatu jaringan tipe khusus, dimana ikatan yang menghubungkan satu titik ke titik lain dalam jaringan adalah hubungan sosial. Hubungan sosial bisa dipandang sebagai sesuatu yang seolah-olah merupakan sebuah jalur atau saluran yang menghubungkan antara satu orang (titik) dengan orang-orang lain dimana melalui jalur atau saluran tersebut bisa dialirkan sesuatu, misalnya barang, jasa, dan informasi. Hubungan sosial antara dua orang 
mencerminkan adanya pengharapan peran dari masing-masing lawan interaksinya. Jaringan sosial telah berkembang terutama dengan munculnya teknologi dan menjadi apa yang kita sebut sebut dengan sosial media. Jaringan sosial seperti youtube memfokuskan diri pada video sebagai visualisasi teks.

\section{Youtube}

Youtube adalah sebuah situs web berbagi video yang dibuat oleh tiga mantan karyawan PayPal pada bulan Februari 2005. Situs ini memungkinkan pengguna mengunggah, menonton, dan berbagi video. Perusahaan ini berkantor pusat di San Bruno, California, dan memakai teknologi Adobe Flash Video dan HTML5 untuk menampilkan berbagai macam konten video buatan pengguna, termasuk klip film, klip TV, dan video musik. Selain itu ada pula konten amatir seperti blog video, video orisinal pendek, dan video pendidikan. Kebanyakan konten di YouTube diunggah oleh individu, meskipun perusahaanperusahaan media seperti CBS, BBC, Vevo, Hulu, dan organisasi lain sudah mengunggah material mereka ke situs ini sebagai bagian dari program kemitraan YouTube. Pengguna tak terdaftar dapat menonton video, sementara pengguna terdaftar dapat mengunggah video dalam jumlah tak terbatas. Video-video yang dianggap berisi konten ofensif hanya bisa ditonton oleh pengguna terdaftar berusia 18 tahun atau lebih. Pada November 2006, YouTube, LLC dibeli oleh Google dengan nilai US\$1,65 miliar dan resmi beroperasi sebagai anak perusahaan Google.

\section{Peta Berjalan (Road Map)}

Peta jalan atau road map adalah sebuah arahan (direction) bagi usaha pengembangan yang bersifat strategis, berskala besar, dan berdurasi panjang. Esensi sebuah peta jalan adalah adanya jalur-jalur (paths) pengembangan yang bila diikuti akan membawa pelakunya mencapai tujuan pengembangan tersebut. Jalur-jalur ini disusun sedemikian rupa dengan memperhatikan berbagai faktor yang melekat pada konteks, situasi, dan lingkungan pengembangan, sehingga dapat mengantarkan pada pencapaian tujuan dengan tingkat efektivitas dan efisiensi yang tinggi. Efektivitas dan efisiensi dicapai melalui proses pengembangan yang terukur dan sistematis. Ada tiga prinsip dasar yang digunakan dalam menyusun langkah dan tahapan pengembangan:

1. Perencanaan yang realistis.

2. Implementasi yang terukur.

3. Kontinuitas antar kegiatan yang terjaga. 
Berikut adalah peta berjalan pada penelitian ini :

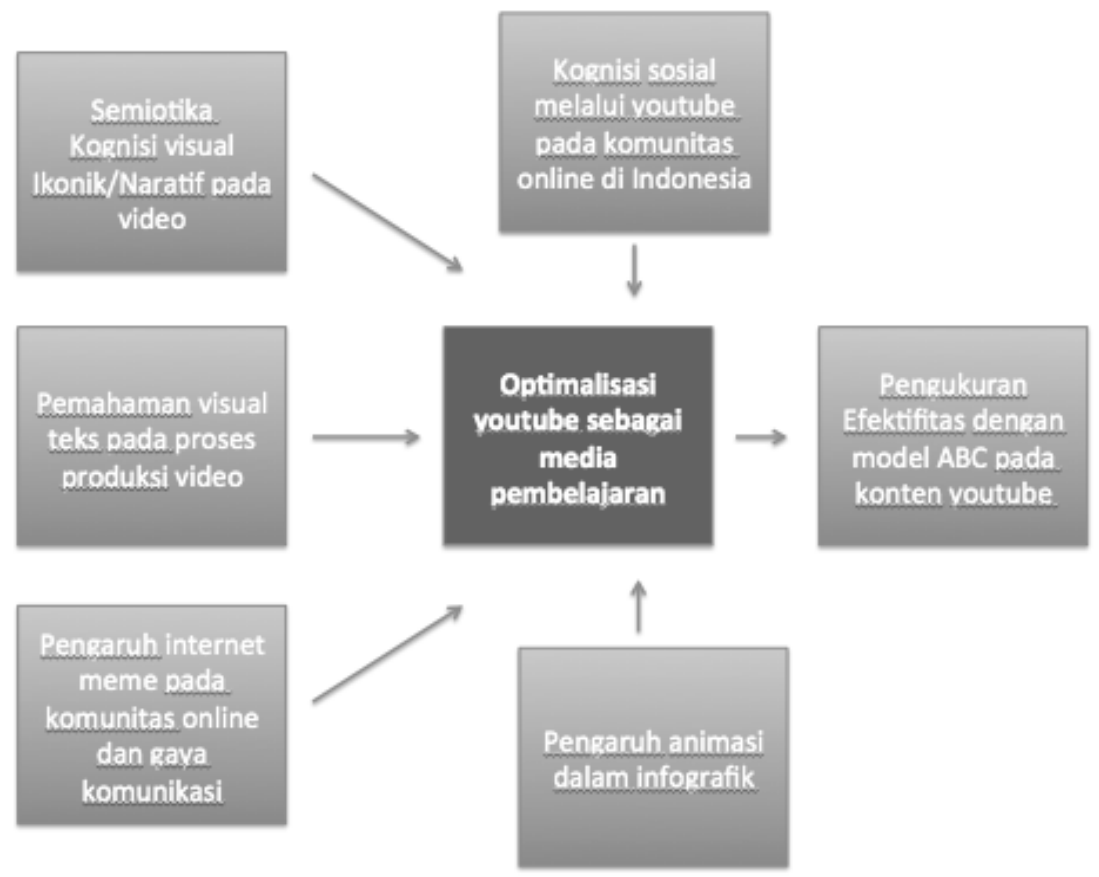

Gambar 1: Peta Berjalan (Road Map)

Penelitian ini merupakam sebuah pendekatan dari serangkaian penelitian yang mencoba mengkaji "optimalisasi Youtube sebagai media pembelajaran" dalam hal ini pada Youtube sebagai situs jejaring sosial yang sangat marak di kalangan anak muda sangat diperlukan bagi komunitas LinkPictureID sebagai referensi informasi dan inspirasi bagi mereka. Mereka sering mengadakan kegiatan berkumpul maupun memproduksi film dan video mereka dengan menggunakan portal video youtube tersebut. Youtube acapkali dijadikan guidance dalam proses pembuatan film mereka.

\section{Metode Penelitian}

Metode penelitian dalam penelitian ini adalah metode penelitian kualitatif. Penelitian kualitatif dilakukan oleh banyak para peneliti dalam ilmu-ilmu sosial dan perilaku. Memahami definisi dari penelitian kualitatif itu sangat penting sebelum peneliti melangkah melakukan penelitian. Menurut Strauss (1990:17) menyatakan bahwa yang dimaksudkan dengan istilah penelitian kualitatif adalah suatu jenis penelitian yang menghasilkan temuan-temuan yang tidak diperoleh oleh alat-alat prosedur statistik atau alat-alat kuantitatif lainnya dalam Ahmadi (2014). 
Dalam penelitian ini berdasarkan cara perolehan dan sumber data maka dibedakan menjadi :

1. Data primer

Menurut Umar (2011) data primer merupakan data yang didapat dari sumber pertama baik dari individu atau perseorangan seperti hasil dari wawancara atau hasil pengisian kuesioner yang biasa dilakukan oleh peneliti. Dalam hal ini peneliti memperoleh data atau informasi langsung dengan menggunakan instrumen-instrumen yang ditetapkan. Data tersebut adalah sebagai berikut :

a. Wawancara

Pengumpulan data primer pada penelitian ini dilakukan dengan wawancara mendalam. Wawancara mendalam adalah suatu cara mengumpulkan data atau informasi dengan cara langsung bertatap muka dengan informan agar mendapatkan data lengkap dan mendalam. Wawancara ini dilakukan dengan frekuensi tinggi (berulang-ulang) secara intensif menurut Kriyantono (2008). Dalam penelitian ini peneliti menggunakan metode wawancara mendalam (depth interview) dengan jenis wawancara tidak terstruktur, adapun wawancara tidak terstruktur adalah wawancara yang tidak berpedoman pada daftar pertanyaan sebelumnya. Adapun narasumber untuk penelitian ini terdapat 3 orang, mereka semua berasal dari Komunitas LinkPictureID yang peneliti wawancarai adalah sebagai berikut :

1. Co-Founder Komunitas LinkPictureID, Bapak Helmi Raffi Putrajaya

2. Ketua Komunitas LinkPictureID, Bapak Fathur

3. Pengelola Komunitas LinkPictureID, Bapak Harris

Ketiga orang tersebut, peneliti anggap layak dan memiliki kredibilitas karena mereka memahami sejarah dari Komunitas LinkPictureID dengan baik serta mereka pun mengetahui dengan baik setiap anggotanya termasuk jadwal rutinitas dari kegiatan komunitas ini.

b. Observasi

Observasi diartikan sebagai kegiatan mengamati secara langsung tanpa adanya mediator suatu objek untuk melihat dengan dekat kegiatan yang dilakukan objek tersebut. Teknik ini menuntut adanya pengamatan dari peneliti baik secara langsung maupun tidak langsung terhadap objek penelitiannya menurut Kriyantono (2008). Peneliti melakukan observasi beberapa kali ke Sekretariat LinkPictureID yang bertempat di Depok II dan juga beberapa tempat pertemuan dari komunitas LinkPictureID seperti Perpustakaan Umum Pemerintah Kota Depok dan Café Ranah Kopi di Jl. Raya Margonda, Depok.

2. Data sekunder

Data sekunder umumnya tidak dirancang secara spesifik untuk memenuhi kebutuhan penelitian tertentu. Seluruh atau sebagian aspek 
dari data sekunder mungkin tidak sesuai dengan kebutuhan suatu penelitian. Beberapa aspek dari data sekunder yang harus di evaluasi oleh peneliti antara lain adalah :

a. Kemampuan data yang tersedia untuk menjawab masalah atau pertanyaan.

b. Kesesuaian antara periode waktu yang tersedianya data dengan periode waktu yang diinginkan dalam penelitian.

c. Kesesuaian antara populasi data yang ada dengan populasi yang menjadi perhatian peneliti.

d. Relevansi dan konsistensi unit pengukur yang digunakan.

e. Biaya yang dikeluarkan untuk mengumpulkan data sekunder.

f. Kemungkinan bias yang dapat ditimbulkan oleh data sekunder.

g. Dapat atau tidaknya dilakukan pengujian terhadap akurasi pengumpulan data dalam Sangadji dan Sopiah (2013).

Data sekunder merupakan data yang didapatkan dari buku serta materi tertulis atau dari hasil penelitian sebelumnya yang relevan dengan tujuan penelitian. Data sekunder ini diperoleh melalui studi kepustakaan baik berupa dokumen atau arsip-arsip tertulis lainnya maupun dokumentasi. Adapun data sekunder yang peneliti gunakan dalam penelitian ini antara lain mengunakan studi pustaka seperti dokumen dan arsip-arsip serta jurnal yang peneliti dapatkan di Perpustakaan Pusat Universitas Pembangunan Nasional Veteran Jakarta, Perpustakaan Fakultas Ilmu Sosial dan Ilmu Politik Universitas Pembangunan Nasional Veteran Jakarta, Perpustakaan Pusat Universitas Indonesia serta toko buku-toko buku yang cukup terkemuka ditambah dengan data-data yang peneliti dapatkan dari googlescholar maupun peneliti langsung mengetik keywordsnya di google.

Analisis data menurut Bogdan dalam Sugiyono (2011) adalah proses mencari dan menyusun secara sistematis data yang diperoleh dari hasil wawancara, catatan lapangan dan bahan-bahan lainnya sehingga dapat dengan mudah dipahami dan temuannya dapat di informasikan kepada orang lain. Analisis data dilakukan dengan mengorganisasikan data ke dalam kategori, menjabarkan ke dalam unit-unit, menyusun ke dalam pola, mengklasifikasikan hal-hal penting yang akan dipelajari dan membuat kesimpulan sehingga mudah untuk dipahami oleh peneliti dan pembaca. Sedangkan menurut Bogden dan Biklen dalam Moleong (2010) menyatakan bahwa analisis data kualitatif adalah upaya yang dilakukan dengan jalan bekerja dengan data, mengorganisasikan data, memilahnya menjadi satuan yang dapat dikelola, mensintesikannya, mencari dan menemukan pola, menemukan apa yang penting dan apa yang dipelajari dan memutuskan apa yang dapat diceritakan kepada orang lain.

Peneliti akan mengambil data wawancara berupa verbatim kemudian teks dialog dalam itu akan diterjemahkan dengan ke dalam konsep - konsep dalam penelitian ini, dan berusaha mengafirmasi gejala - gejala pada konsep. Namun 
Fitria Ayuningtyas, Ahmad Zakki Abdullah : Kognisi Sosial Melalui Situs Jejaring Youtube Pada Komunitas Online (Studi Kasus pada Komunitas Online LinkPictureID)

demikian akan ada upaya dalam mencari indikasi perkembangan yang berhubungan dengan lokalitas dan acuan yang mengkaitkan dengan kebiasaan ataupun budaya setempat melalui probing. Hal ini pun kemudian menjadi acuan yang sangat penting karena peneliti harus bisa membedakan antara teks - teks ini dengan adanya pengaruh dari peneliti . Analisis deskriptif positifis ini merupakan langkah yang cukup karena mengacu pada penguatan kualitas teori sebelum kemudian bisa dilakukan penelitian yang lebih spesifik.

\section{Hasil Penemuan dan Diskusi}

Berdasarkan hasil observasi yang telah peneliti lakukan beberapa kali ke Sekretariat LinkPictureID yang bertempat di Depok II dan juga beberapa tempat pertemuan dari Komunitas LinkPictureID seperti Perpustakaan Umum Pemerintah Kota Depok dan Café Ranah Kopi di Jl. Raya Margonda, Depok, Komunitas pengguna merupakan salah satu wadah yang sangat menarik untuk dikaji, selain pembentuk aset sosial yang dinamis ada sebuah mentalitas sosial yang terbentuk akibat interaksi para penggunanya. Dalam studi kasus ini, LinkPictureID adalah sebuah komunitas kecil yang sebenarnya memulai aktivitasnya dengan berbagi informasi tentang film dan kegiatan lainnya yang berhubungan dengan workshop film atau produksi film pendek di lingkungan sekitar kota Depok. Dalam upaya mengadakan kegiatan berkumpul maupun memproduksi film dan video mereka sering kali menggunakan portal video youtube sebagai referensi informasi dan inspirasi mereka. Komunitas ini sering sekali menggadakan acara sekedar sharing atau kumpul-kumpul di Perpustakan Umum Pemerintah Kota Depok dan Café Ranah Kopi tersebut, mereka jarang melakukannya di Sekretariat LinkPictureID karena terbatasnya tempat yang ada.

Berdasarkan hasil wawancara yang tidak terstruktur kepada Co-Founder Komunitas LinkPictureID, Youtube acapkali dijadikan guidance dalam proses pembuatan film mereka. Kesempatan yang sangat terbuka untuk bisa berkecimpung di dunia youtube adalah sebuah dorongan untuk membentuk sebuah jaringan yang luas yang bertujuan untuk menambah kapital sosial. Dalam jaringan tersebut diyakinkan memiliki banyak kesempatan untuk tidak hanya menambah wawasan namun berkenalan, kerjasama dan bahkan bekerja. Komunitas online LinkPictureID menggunakan berbagai media sosial lainnya, namun youtube menjadi salah satu jaringan yang terpenting karena pada intinya mereka bertujuan untuk menghasilkan interaksi yang dinamis. Menurut Ketua Komunitas LinkPictureID, kesempatan ini digunakan lebih maksimal oleh komunitas ini dengan adanya adsense atau monetisasi konten video pada youtube. Dengan adanya adsense, pengguna dapat membuat channel dan bisa menghasilkan uang dengan cara memperbolehkan iklan untuk muncul pada videonya. Kognisi sosial yang terbentuk dalam hal ini adalah pandangan tentang dunia bisnis yang mengandalkan video sebagai alat jual mereka. Mereka pun sudah mengenal istilah creativeprenuer sebagai sosok pengusaha muda yang mengandalkan kreatif.

Menurut Pengelola Komunitas LinkPictureID dalam hal ini juga kreativitas menjadi salah satu konsep yang turut menyumbang bagaimana kognisi 
mereka terhadap masyarakat terkini. Bahwa sekarang diberikan sebuah kesempatan kepada siapa saja, dan terbuka secara bebas untuk bisa berpartisipasi dalam dinamikan ini dengan berkesempatan mendapatkan imbalan (adsense). Kognisi sosial melalui youtube memberikan pandangan bahwa kita bisa berkreasi sebaik mungkin untuk bisa berkarya secara bebas. Adapun penggunaan referensi biasanya menggunakan pengguna youtube lainnya sebagai pembanding.

Youtuber atau para pengguna youtube aktif yang telah mendapatkan status sosial ini dikenal sebagai orang - orang yang terdepan dalam produksi youtube. Keaktifan mereka dalam membuat video sangat berpengaruh pada kognisi sosial, selain mendapatkan informasi dari youtube para youtuber sering kali mengadakan acara secara offline. Disini komunitas LinkPictureID sering berinteraksi dengan mereka dengan harapan dapat mengambil pembelajaran tentang trend dan produksi video.

Dalam hal ini, komunitas LinkPictureID paham dengan konsep "upgrade" dimana diperlukan sebuah kecepatan dalam mengambil keputusan berdasarkan dinamika yang terjadi. Ini juga menjadi sebuah acuan yang sangat penting, karena pada era teknologi sekarang para pengguna memerlukan cara untuk meningkatkan ilmu atau pengetahuan dalam memaksimalkan atau mencari cara yang lebih efektif dalam menyampaikan pesan.

Youtube adalah sebuah portal video yang pada mulanya hanya menawarkan sebuah wadah dimana kita bisa menaruh video dan kawan kawan kita bisa berkomentar pada video tersebut. Perkembangan fitur channel, playlist dan adsense akhirnya membentuk sebuah model bisnis yang sangat menguntungkan. Secara garis besar, youtube telah menjadi sebuah "penyiaran" yang berbasis pengguna. Dimana para pengguna bisa mendapatkan keuntungan melalui isi pada video dengan disisipi iklan.

Model interaksi ini mendorong para pengguna untuk lebih aktif dalam mendapatkan untung, namun tentu dengan ilmu dan pengetahuan tentang produksi video. Dalam upaya ini, ada sebuah interaksi yang dinamis dalam komunitas online LinkPictureID maupun diluar komunitas. dorongan untuk mencari informasi terbaru mengenai konsep dan wacana trending untuk dijadikan konten video telah menjadi dorongan atau determinisme para anggota komunitas. Kognisi sosial ini akhirnya membentuk sebuah mentalitas pengusaha muda dengan menggunakan media sebagai alat pencari keuntungan dan sumber pendapatan untuk kehidupan sehari-hari. Bagaimana mereka mengintegrasikan pandangan mengenai bisnis maupun sosial telah menyatu. Namun demikian diperlukan sebuah pandangan lain terutama masalah etika dan cara menyikapi perkembangan ini, karena akhirnya masalah "upgrade" yang disebutkan sebelumnya juga turut mempengaruhi kemampuan kogniti mereka selanjutnya.

\section{Simpulan}

Sebuah perilaku pengguna yang sangat agresif terhadap pendapatan Adsense belakangan sangat mencolok terutama di kota-kota besar. Hal ini memang harus dibahas lebih lanjut dengan tujuan dapat membentuk kelayakan dan kepantasan pada penggunaan youtube. Terutama menumbuhkan kesadaran 
Fitria Ayuningtyas, Ahmad Zakki Abdullah : Kognisi Sosial Melalui Situs Jejaring Youtube Pada Komunitas Online (Studi Kasus pada Komunitas Online LinkPictureID)

pada sebuah komunitas tentang pengelolaan pengetahuan dengan menggunakan youtube. Bahwa sekarang diberikan sebuah kesempatan kepada siapa saja, dan terbuka secara bebas untuk bisa berpartisipasi dalam dinamikan ini dengan berkesempatan mendapatkan imbalan (adsense). Kognisi sosial melalui youtube memberikan pandangan bahwa kita bisa berkreasi sebaik mungkin untuk bisa berkarya secara bebas. Adapun penggunaan referensi biasanya menggunakan pengguna youtube lainnya sebagai pembanding. Dalam hal ini, komunitas LinkPictureID paham dengan konsep "upgrade" dimana diperlukan sebuah kecepatan dalam mengambil keputusan berdasarkan dinamika yang terjadi. Ini juga menjadi sebuah acuan yang sangat penting, karena pada era teknologi sekarang para pengguna memerlukan cara untuk meningkatkan ilmu atau pengetahuan dalam memaksimalkan atau mencari cara yang lebih efektif dalam menyampaikan pesan.

\section{Ucapan Terima Kasih}

Dalam pelaksanaan penelitian ini, tim peneliti ingin banyak mengucapkan terima kasih kepada beberapa pihak sebagai upaya apresiasi kami sehingga penelitian ini dapat terlaksana dengan baik dan lancar. Apresiasi ini kami sampaikan kepada pihak-pihak antara lain:

1. Mitra kerja kami dalam program ini yakni komunitas videographer LinkPictureID dan Dakwah Multimedia.

2. HexPicture sebagai mitra media dan pemberi data.

3. Dinas Kominfo di Pemerintah Kota Depok yang banyak memberikan rekomendasi terhadap komunitas di Depok.

\section{Daftar Pustaka}

Ahmadi, Rulam. (2014). Metodologi Penelitian Kualitatif. Yogyakarta: ArRuzzmedia.

Arti Pengertian Jariangan Sosial. (n.d.). Retrieved Maret 10, 2017, from Arti Definisi Pengertian: http://arti-definisi-pengertian.info/pengertianjaringan-sosial/

Chau, Clement. (2010). YouTube as a participatory culture. New Directions for Youth Development, vol 2010, issue 128.

Khatchatourian, Maane. (n.d.). YouTube Star PewDiePie Earned \$12 Million Last Year. Retrieved Maret 15, 2016, from Variety: http://variety.com/author/maane-khatchatourian/

Kriyantono, Rachmat. (2008). Teknik Praktis Riset Komunikasi. Jakarta: Kencana Prenada Media Group.

Moleong, J. Lexy. (2010). Metode Penelitian Kualitatif. Bandung: PT. Remaja Rosdakarya.

Pengertian Kognisi Sosial. (n.d.). Retrieved Mei 10, 2017, from Psikologi Sosial: http://www.psikologiku.com/pengertian-kognisi-sosial-dalam-psikologisosial/

Postigo, Hector. (2014). The socio-technical architecture of digital labor: 
Converting play into YouTube money, New Media and Society

Sangadji, Etta Mamang., \& Sopiah. (2013). Perilaku Konsumen. Yogyakarta: Penerbit Andi.

Stark, Chelsea. (2015, Juli 22). PewDiePie's YouTube success put him on the cover of 'Variety'. Retrieved Maret 15, 2016, from Mashable: http://mashable.com/2015/07/22/pewdiepie-variety/\#cZPIz.Af.OqS

Sugiyono. (2011). Metode Penelitian Kombinasi (Mixed Methods). Bandung: Afabeta.

Umar, Husein. (2011). Metode Penelitian Untuk Skripsi dan Tesis Bisnis. Jakarta: PT. Raja Grafindo Persada. 